\title{
ラグランジュ型粒子モデルによる 排煙上昇過程を含む大気拡散の予測
}

\author{
市川陽一1・赤井幸夫 ${ }^{2} \cdot$ 佐田幸一 3 \\ ${ }^{1}$ 正会員 工博 （財）電力中央研究所 大気科学部（广201-8511 東京都狛江市岩戸北2-11-1） \\ 2 (財) 電力中央研究所 大気科学部 (广201-8511 東京都狛江市岩戸北2-11-1) \\ ${ }^{3}$ 工博 （財）電力中央研究所 大気科学部（广201-8511 東京都狛江市岩戸北2-11-1）
}

\begin{abstract}
ラグランジュ型粒子モデルによって，排煙上昇過程を含む大気拡散の予測を行った．本モデルの支配方 程式は, 粒子のランダムな運動を表す確率微分方程式で, 鉛直成分の式には浮力による加速度項が付加さ れている. 数值モデルの予測結果を検討するために, 実煙源の排煙を対象としたライダー観測と野外トレ 一サ実験を実施した．排煙上昇軌跡について，数値モデルとライダー観測の結果によい一致が得られた. 数值モデルで予測した拡がり幅は, ライダー観測の結果より大きかったが, これは前者が時間平均值, 後 者が瞬間的な值を示すことを考えれば説明ができる．本モデルを実地形へ適用し，野外トレーサ実験の結 果をもとに妥当性を確認した。
\end{abstract}

Key Words : dispersion model, Lagrangian particle model, plume rise, Lidar observation, field tracer experiment

\section{1.はじめに}

近年，流体の運動や物質の移動を計算機で解く数 值解析技術は，高速計算機の普及にともない，飛躍 的に進歩を遂げた．大気拡散の分野でも，気流や排 ガス拡散に関する多くの数值モデルが提案されてい る. 大気拡散の予測を合理的，効率的に行うには， 数値モデルの活用が不可欠となってきたと言える.

地形や熱によって生じる複雑な流れ場に適用でき る優れた大気拡散モデルの一つが, ラグランジュ型 粒子モデルである。その中でも，Thomson"によよ て提案されたモデルは, 非正規, 非均質場への適用 性と正規乱数の使用という面で, 従来のモデルに優 る. ラグランジュ型粒子モデルの特徵と開発の現状 については，筆者ら ${ }^{2)}$ のよめがある. Thomsonの モデルは, 対流境界層内の拡散解析に適用された事 例 ${ }^{3) ， 4)}$ はあるが，地形上の拡散予測に使われたこ とはなかった、筆者ら ${ }^{51}$ は Thomson のモデルを実 地形上の 3 次元拡散の予測に適用し, 計算結果の妥 当性を風洞実験結果をもとに確認した。しかし，そ の際，ほとんどの拡散予測と同様に排煙上昇過程を
考慮しなかった。排煙の挙動をより篇密に扱うには, 上昇過程を含めて拡散モデルを構筑する必要がある. 特に，煙源の近くに煙源高さに比べて相対的に高い 地形, 建物がある場合や熱の影響が強い対流境界層 内では，排煙上昇過程が地物や熱の影響を受ける. そのような場合の濃度予測に，排煙上昇過程を考慮 した拡散モデルは役に立つ。

本研究ではラグランジュ型粒子モデルに排煙上昇 過程を組み込んだ。そして，実煙源の排煙を対象に ライダー観測を実施し，数值モデルの上昇過程の予 測精度をまず検討した．次に，排煙上昇過程を含め て数值モデルで拡散計算し, 野外トレーサ実験の結 果と比較することにより，予測の妥当性を確かめた. 本研究は通商産業省資源エネルギ一庁からの受託 研究として実施した。

\section{2. 数値モデル}

ラグランジュ型粒子モデルの支配方程式は, 以 下に示す確率微分方程式で与えられる. 


$$
d u^{i}=a^{i}(x, u, t) d t+b^{i j}(x, u, t) d \xi^{j}
$$

$d x=u d t$

ここで，u， $\mathbf{x}$ はそれぞれ粒子あるいは流体要素の 速度ベクトル，位置ベクトル， t は時間， a は動特 性の影響を表す係数, b は雑音の影響を表す係数， $\mathrm{d} \xi$ はウィナー過程の增分である.また, 添字 $\mathrm{i}$ は $\mathrm{x}, \mathrm{y}, \mathrm{z}$ 成分を表す。なお, 本報告では添字 $\mathrm{j}$ お よび以下の式で現れる k，1にアインシュタインの 規約を適用して式を記述している.

式(1)の係数 $b^{\mathrm{ij}}$ はラグランジュ速度の構造関数 の定義とその関数形により次式で与えられる ${ }^{11}$.

$$
b^{i j}=\delta^{i j} \sqrt{\mathrm{C}_{0} \varepsilon}
$$

ここで, $\delta^{i j}$ はクロネッカーのデルタ関数， $\varepsilon$ はエ ネルギーの散逸率である.Co はラグランジュ速度 の構造関数に対する普遍定数である.C C の值は Rodean ${ }^{6)}$,Du ら ${ }^{7}$ のまとめによると $1 \sim 10$ である. 本研究の排煙上昇過程の予測では, 筆者ら ${ }^{5)}$ が風 洞内の拡散予測でよい結果を得た 3.0 を用いた。

Thomson ${ }^{11}$ は，正規乱れの場に対して，係数 a を 評価する以下の式を提案した.

$$
a^{i}=-\mathrm{B}^{i j}\left(\mathbf{V}^{-1}\right)^{k}\left(u^{k}-\mathrm{U}^{k}\right)+\phi^{i} / g_{a}
$$

ここで，

$$
\begin{aligned}
& \frac{\Phi^{i}}{g_{a}}=\frac{1}{2} \frac{\partial V^{i l}}{\partial x^{l}}+\frac{\partial U^{i}}{\partial t}+U^{l} \frac{\partial U^{i}}{\partial x^{l}} \\
& +\left\{\frac{1}{2}\left(\mathbf{V}^{-1} y^{j}\left(\frac{\partial \mathbf{V}^{i l}}{\partial t}+\mathrm{U}^{m} \frac{\partial \mathrm{V}^{i l}}{\partial x^{m}}\right)+\frac{\partial \mathrm{U}^{i}}{\partial x^{j}}\right\}\left(\boldsymbol{w}^{j-\mathrm{U}^{j}}\right)\right. \\
& +\frac{1}{2}\left(\mathbf{V}^{-1} y_{j} \frac{\partial \mathbf{V}^{i l}}{\partial x^{k}}\left(u^{j}-U^{j}\right)\left(u^{k}-U^{k}\right)\right. \\
& \mathbf{U}=\left\langle\rho u_{\mathrm{E}}\right\rangle\langle\rho \rho\rangle \\
& V^{i j}=\left\langle\rho\left(u_{\mathrm{E}^{j}-U^{i}}\right)\left(u_{\mathrm{E}}^{j}-U^{j}\right)\right\rangle\langle\rho \rho\rangle \\
& \mathrm{B}^{i j}=b^{i k} b^{j k} / 2
\end{aligned}
$$

で，gaは正規乱れを表す流体要素の密度関数，U は平均流速，夦はオイラ一的な速度， $\rho$ は密度， く>はアンサンブル平均, $\mathrm{V}$ は応カテンソルである. $\mathrm{U}, \mathrm{uE}_{\mathrm{E}}, \mathrm{V}$ の添字 $\mathrm{i}, \mathrm{j}$ はベクトルあるいはテンソ ルの成分を表す。

排煙上昇過程を考慮するには，式(1)の鉛直成分 を表す式に，浮力による粒子上昇の加速度項を付 け加えるとよい，ここで， $\mathrm{u}^{\mathrm{i}}$ の $\mathrm{z}$ 成分，つまり鉛 直方向の速度成分を $\mathrm{w}$ と表す.

$$
d w=a d t+b d \xi+\left(\frac{d w_{c}}{d t}\right) d t
$$

ここで，W.は浮力による排煙上昇速度である． Luhar and Britter ${ }^{8 /}$ は $W_{c}$ の評価を Slawson and Csanady ${ }^{9}$ をもとに行った. 彼らは, 大気乱流より もプルーム本体の運動による乱れが支配的な初期 段階, 大気中の慣性小領域の渦が支配的な中間段 階，大きな渦を含む大気乱流が支配的な最終段階 に分け，物質収支式をたてて上昇軌跡とプルーム の半径 Rを導いている．それらをもとに，W。は以 下の式で与えられる。

初期段階 :

$$
w_{c}=\frac{d z_{c}}{d t}=\left(\frac{4}{9 \beta^{2}}\right)^{1 / 3} \mathrm{~F}_{b}^{1 / 3} x^{-1 / 3}
$$

ここで， $\mathrm{Z}$ 、は煙源位置からの排煙上昇高度， $\beta$ は エントレインメント係数 $(=0.6), F_{\mathrm{b}}$ は浮力フラッ クスである。

中間段階 :

$$
w_{c}=\frac{\mathrm{R}_{1}{ }^{2} w_{c 1}+\mathrm{F}_{b}\left(x-x_{1}\right) \overline{u^{2}}}{\mathrm{R}^{2}}
$$

ここで，

$$
\mathrm{R}^{2}=\left\{\mathrm{R}_{1}^{2 / 3}+2 a_{1} \varepsilon^{1 / 3}\left(x-x_{1}\right)(3 \bar{u})\right\}^{3}
$$

可は平均風速， $\mathrm{a}_{1}$ は係数で 0.9 である. 添字 1 は 中間段階の始まりにおける值を意味する.

最終段階:

$$
w_{c}=\frac{\mathrm{R}_{2}^{2} w_{c 2}+\mathrm{F}_{b}\left(x-x_{2}\right) \overline{u^{2}}}{\mathrm{R}^{2}}
$$

ここで， 


$$
\mathrm{R}^{2}=\mathrm{R}_{2}^{2}+2 a_{2} \sigma \mathrm{L}\left(x-x_{2}\right) \bar{u}
$$

$\mathrm{a}_{2}$ は係数で 4, $\sigma$ は速度変動の標準偏差，Lは渦 の長さスケールである. 添字 2 は最終段階の始ま りにおける值を意味する.

式(10)は排煙上昇が風下距離の $2 / 3$ 乗に比例す ることを表している. Slawson and Csanady9)によれ ば，この $2 / 3$ 乗則は煙源のごく近くではすべての 大気安定度に対して妥当であるが, 安定時, 不安 定時には, 風下距離が大きくなるにつれて, 排煙 上昇は $2 / 3$ 乗則に従わなくなる.そこで, 本研究 では, Slawson and Csanady9 の論文に立ち返り，非 中立時には大気安定度を考慮した次式から Wc を求 めた。

$$
w_{c}=\frac{\bar{u}^{2} l}{\mathrm{R}^{2} \mathrm{~N}} \sin \left(\frac{\mathrm{N} x}{\bar{u}}\right)
$$

ここで，

$$
\begin{gathered}
l=\frac{\mathrm{F}_{b}}{\bar{u}^{3}} \\
\mathrm{~N}^{2}=-\frac{g}{\rho_{1}} \frac{d \rho_{a}}{d z} \fallingdotseq \frac{g}{\mathrm{~T}_{1}} \frac{d \theta_{a}}{d z}
\end{gathered}
$$

$\mathrm{N}$ はブラント・バイサラの振動数, $\mathrm{g}$ は重力の加 速度, $\theta_{a}, \rho_{\mathrm{a}}, \mathrm{T}$ は順に温位, 密度, 絶対温度で, 添字 1 は代表值を表す. 初期段階の $\mathrm{R}$ は次式で与 えられる。

安定時 :

$$
\begin{gathered}
\mathrm{R}^{3}=\left[3 \beta l \bar{u}^{2} / \mathrm{N}^{2} I(2 n-1)+(-1)^{n} \cos (\mathrm{N} x / \bar{u})\right] \\
(n=1,2,---)
\end{gathered}
$$

不安定時 :

$$
\mathrm{R}^{3}=\frac{3 \beta l \bar{u}^{2}}{\mathrm{~N}^{2}}\left(\cosh \frac{\left|\mathrm{N}^{2}\right|^{1 / 2} x}{\bar{u}}-1\right)
$$

本研究では，排煙上昇過程を組み込んだ拡散モ デルを実地形へ適用する.地形境界における粒子 の挙動は, 完全反射を仮定して, 以下のように扱 った. 完全反射後の粒子の位置 $\mathbf{x}$ 'は次式で計算で きる.

$$
x^{\prime}=x-2 n\left\{n \cdot\left(x-x_{p}\right)\right\}
$$

ここで， $\mathbf{x}$ は粒子が地面で反射せず入射した場合 の位置， $\mathrm{x}_{\mathrm{p}}$ は粒子の地面への入射あるいは反射位 置である. $\mathbf{n}$ は次式に示す法単位べクトルである.

$$
n=\frac{-z_{g x} i-z_{g y} j+k}{\left(1+z_{g x}{ }^{2}+z_{g y}{ }^{2}\right)^{1 / 2}}
$$

ここで, $\mathrm{z}_{\mathrm{g}}=\mathrm{z}_{\mathrm{g}}(\mathrm{x}, \mathrm{y})$ は地形標高, $\mathrm{z}_{\mathrm{g} x}, \mathrm{z}_{\mathrm{g} y}$ はそ れぞれ $\mathrm{z}_{\mathrm{g}}$ の $\mathrm{x}, \mathrm{y}$ 方向の偏微分を表す．同様に， 反射後の粒子の速度は次式で求めることができる.

$$
\boldsymbol{u}^{\prime}=\boldsymbol{u}-2 \boldsymbol{n}(\boldsymbol{n} \cdot \boldsymbol{u})
$$

実地形内の大気拡散計算に必要な乱流統計量は, 乱流クロージャーモデルの計算結果から与えた. 乱流クロージャーモデルは地形に沿った座標系で， 連続の式, 運動方程式, エネルギー方程式および 乱流エネルギー, エネルギーの散逸率, 温位乱れ の輸送方程式を解くものである.乱流モデルは Gibson and Launder ${ }^{10}$ によって開発されたレイノル ズ応力モデルにもとづいている．レイノルズ応力 方程式の移流項, 拡散項は簡略化され, レイノル ズ応力は代数方程式で表された。また，乱流量の 水平方向勾配を含む項が，鉛直方向勾配を含む項 と比べて小さいとみなして省略する境界層近似， 鉛直方向の気圧傾度力が重力による空気の重さに 等しい力と釣り合うという静力学平衡の仮定, 観 測風のデータをもとに流れ場を修正する 4 次元同 化法が導入されている。方程式系などの詳細は Sada et al. ${ }^{11)}$ に記載されてる. 4 章の排煙上昇過程 の予測では, 必要な乱流統計量は煙源地点の観測 データから与えた。ただし，エネルギーの散逸率 については観測できないので，上記の乱流クロー ジャーモデルの計算結果を用いた。

\section{3. 野外実験}

排煙上昇過程のモデルおよび排煙上昇過程を組 み込んだ拡散モデルの妥当性を検討するために， 野外実験を実施した。実験は 1995 年 8 月 23 日に 浮カフラックスが $320 \sim 330 \mathrm{~m}^{4} / \mathrm{s}^{3}$, 高さが $200 \mathrm{~m}$ の 煙突を対象に行った。対象煙源の規模は比較的大 きい. 周辺地形の特徵は 5 章で述べる. なお, 浮 カフラックス $\mathrm{Fb}$ は次式で与えられる. 


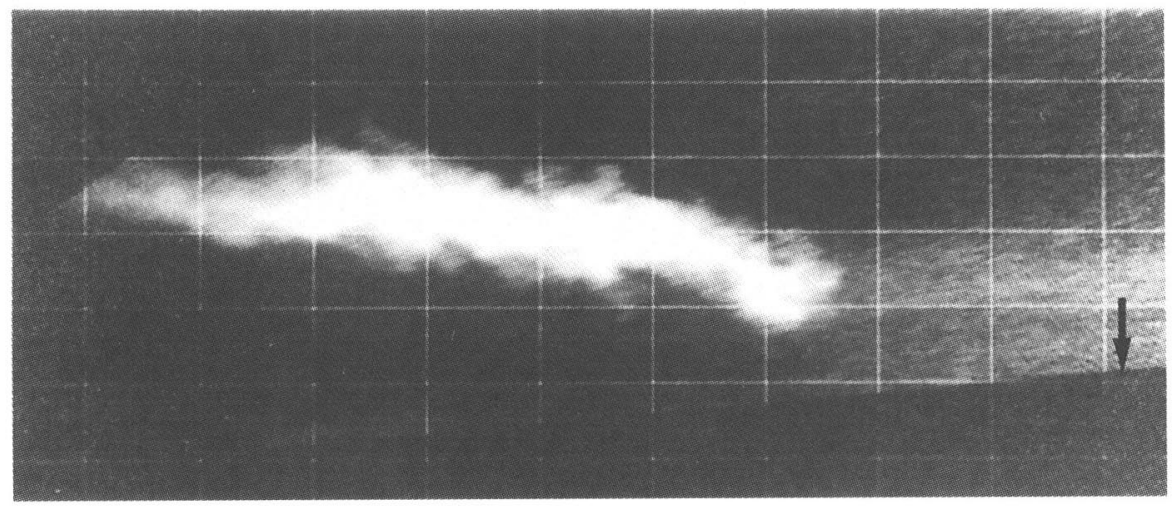

図一 1 ライダーによる排煙上昇の 観測結 果

表 - 1 排 煙上昇 観 測中 の気象条件

\begin{tabular}{|lllllccccc|}
\hline 時刻 & $\mathrm{u}(\mathrm{m} / \mathrm{s})$ & $\mathrm{T}\left({ }^{\circ} \mathrm{C}\right)$ & $\mathrm{zi}(\mathrm{m})$ & $\sigma_{\mathrm{v}}(\mathrm{m} / \mathrm{s})$ & $\sigma_{\mathrm{w}}(\mathrm{m} / \mathrm{s})$ & $\mathrm{N}^{2}\left(\mathrm{~s}^{-2}\right) \varepsilon$ & $\left(\mathrm{m}^{2} \mathrm{~s}^{-3}\right)$ \\
\hline 1 & 1 & 時 & 3.3 & 27.6 & 1400 & 0.20 & 0.20 & $1.89 \times 10^{-4}$ & $1.68 \times 10^{-4}$ \\
1 & 2 時 & 4.1 & 27.6 & 1300 & 0.28 & 0.28 & $2.61 \times 10^{-5}$ & $1.57 \times 10^{-3}$ \\
1 & 3 時 & 3.5 & 28.3 & 1300 & 0.48 & 0.48 & $1.56 \times 10^{-4}$ & $3.63 \times 10^{-3}$ \\
1 & 4 時 & 3.7 & 29.2 & 1200 & 0.97 & 0.77 & $1.23 \times 10^{-4}$ & $6.54 \times 10^{-3}$ \\
1 & 5 時 & 7.4 & 30.5 & 1200 & 0.89 & 0.89 & $2.58 \times 10^{-5}$ & $1.22 \times 10^{-2}$ \\
\hline
\end{tabular}

$\mathrm{F}_{b}=w_{0} \mathrm{R}_{0}^{2} \cdot g(\Delta \rho / \rho)_{0}$

ここで，woは排ガス吐出速度（20m/s），Roは煙 突半径 $(5 \mathrm{~m}) ，(\Delta \rho / \rho)$ 。は大気の密度に対する 煙突出口における排ガスと大気の密度差の比であ る. 浮力フラックスは体積フラックス（慣習的に $\pi$ は省く $\left.{ }^{12}\right)$ と単位質量あたりの浮力の積で, 浮

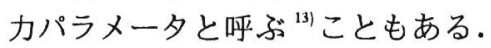

実験当日は晴れで，日中，地表近くには熱的に 不安定な境界層が発達した。煙の輪郭を把握する 排煙上昇過程の観測には, 午前中の熱の影響があ まり強くない時間帯が適していた。一方, 午後は 熱と地形の複合効果を調べる野外トレーサ実験に 適していた。

排煙上昇過程の観測はライダーにより行った。 用いたライダーは，大気環境観測に実績豊かな米

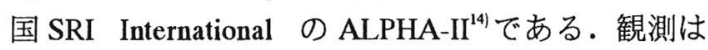
SRI International の協力を得て実施した.ライダー はパルスレーザーを大気に向けて射出し，粒子あ るいは気体によって後方散乱した光を受け，これ
を電気信号に変換して煙等の位置を計測する装置 である. ALPHA-II では, $1.064 \mu \mathrm{m}$ と $0.532 \mu \mathrm{m}$ の 2 つのレーザー波長（パルスエネルギーはそれぞ れ $100 \mathrm{~mJ}$ と $40 \mathrm{~mJ}$ ) を用いることができるが, 今回 は予備試験の結果, 煙からの強い散乱が得られた 後者を主に用いた。

図ー 1 はライダーによる排煙の観測結果例であ る. 右側の矢印先端が煙突出口（高さ $200 \mathrm{~m}$ ) で, 白線の格子一つの大きさは横方向が $150 \mathrm{~m}$, 高さ 方向が $100 \mathrm{~m}$ である. 観測は, 風向などから排煙 の位置を予想して狙いを定め, 一つの方位で高度 方向に 5 度から 35 度まで約 20 回走査して行った。 図で白っぽくなっているところが排煙で，この排 煙の下縁から斜め上方にレーザー光が通過してい る. 煙が高さ $300 \sim 500 \mathrm{~m}$ まで上昇しているのが わかる.このような画像デー夕から得られた上昇 高さあるいは煙の拡がり幅が一つの観測デー夕に なる.そのため, 一つの観測デー夕における変動 は把握できない。表ー 1 はライダ一観測を実施し たときの煙源位置における気象条件を示している。 風速 $\mathrm{u}$, 気温 $\mathrm{T}$ は低層ゾンデ（日本気象協会 
JWA-94W 型) の測定結果, 境界層厚さ $\mathrm{z}$ i は低層 ゾンデで測った気温鉛直分布の逆転から判断した 值, 水平方向, 鉛直方向の風速変動の標準偏差 $\sigma_{\mathrm{v}}$, $\sigma_{\mathrm{w}}$ はドップラーソーダ (カイジョー AR-410 型) の 10 分平均観測值, $\mathrm{N}$ は式(17)に示すブラント. バイサラの振動数, エネルギーの散逸率 $\varepsilon$ は乱流 クロージャーモデルの計算結果である. $\mathrm{N}$ は地上 $150 \mathrm{~m}$ と $250 \mathrm{~m}$ の温位勾配から求めた。 $Z_{i}$ は式 (14)のLを計算するのに用いる． L = $0.7 \mathrm{Zi}$ であ る ${ }^{8)}$.

ライダー観測と同じ日に，同じ煙源を対象に $\mathrm{SF}_{6}$ トレーサ実験を実施した。トレーサガスは煙 道に炊き込み, 排ガスと一緒に煙突から放出した. トレーサガスはサンプリングの数時間前から放出 し，エアーバッグを用いて 30 分間かけて捕集した. $\mathrm{SF}_{6}$ の分析は非放射線型 $\mathrm{ECD}$ 付きガスクロマトグ ラフ装置で行った。サンプリング用のエアーバッ グは，煙源からおよそ $3,6,10,15,20,25 \mathrm{~km}$ の距離 の地上に, 円弧状に合計で約 60 地点配置した.

\section{4. 排煙上昇過程の予測}

図ー 2 は排煙上昇軌跡の計算結果と観測結果の 比較を示している。排煙上昇軌跡は, 計算結果の 場合は濃度の最も高い位置, 観測結果の場合はラ イダー受信信号のピーク位置を表している．数値 モデルによる予測は，低層ソンンデの観測間隔に合 わせて, 毎時刻 0 分 10分の気象デー夕を用いて 行っている.これに対し, 観測結果は毎時刻 0 分 から59 分の間に，方位を定めた観測を $2 \sim 5$ 回実 施して取得されたものである。また，計算結果は 時間平均モデルを用いているため定常的な值, 観 測結果は 1 走査あたりのレーザー光の照射が 1 分 以内なので瞬間的な短時間值を示す. 图一 3 は排 煙上昇高さについて, 数值モデルの計算值と観測 値を比較した結果である.排煙上昇高さの全デー 夕平均で見ると，数值モデルは観測結果を約 $20 \%$ 過大評価している。大気拡散予測の観点からは， 上昇高さに煙突実高を加えた排煙高さで考えた方 がよい.この場合, 数值モデルの過大評価は約 10 \%になり，大きな誤差とは言えない。また，観測 データが瞬間的な短時間值でばらつきがあること, 1 時間の間に起こる気象変化の影響を受けている ことを考慮に入れる必要がある。このことは, ラ イダーの画像が最も安定した時間帯の観測結果の 平均值で比較するとよくわかる. 計算を 12 時の気 象条件を用いて行い，観測結果を 11 時 21 分〜 12 (a) 11 時

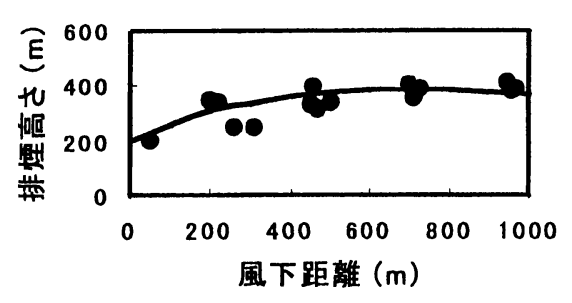

(b) 12 時

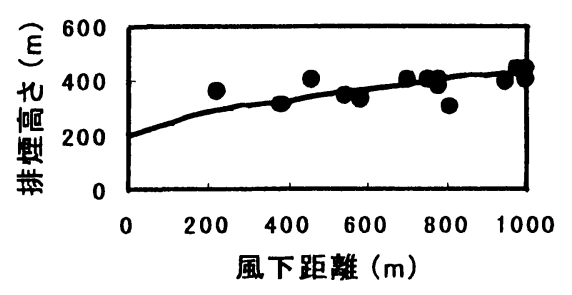

(c) 13 時

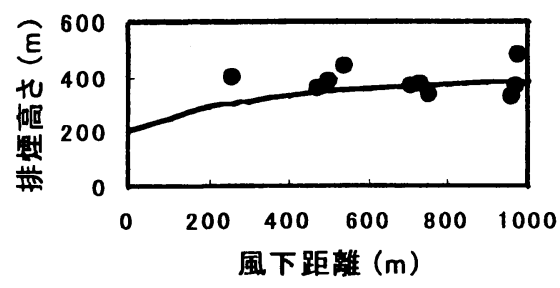

(d) 14 時

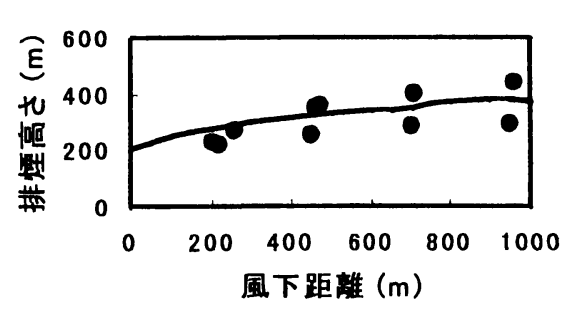

(e) 15 時

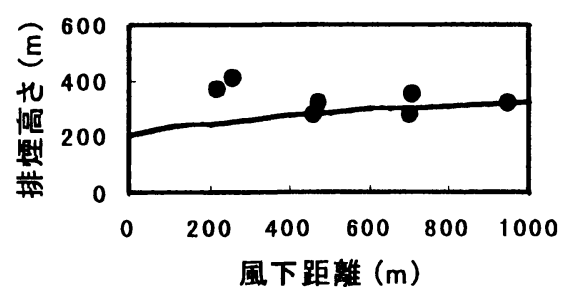

図-2 排煙上昇軌跡の計算結果と観測結果の比較 (一：計算結果，○：観測結果) 


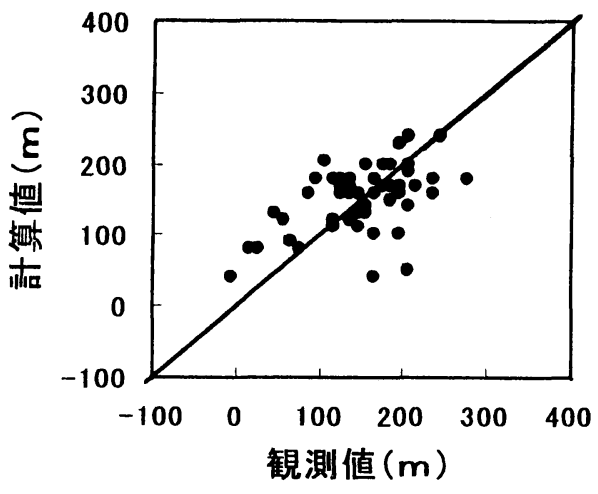

园－3 排煙上昇高さの計算結果と観測結果の比較

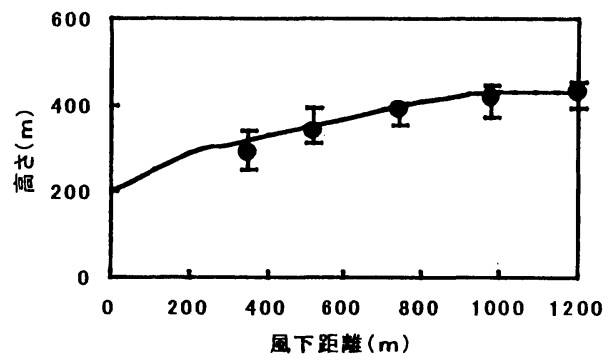

图-4 排煙上抙軌跡の計算結果と観測結果の

比較：観測値は 6 回分の平均

(一：計算結果, ○: 観測結果の平均, I : 観測値の最大と最小の幅)

時 29 分の 6 回分の平均值で表した結果が図ー4で ある、計算値と観測值はよく一致している。

図ー 5 は鉛直方向の煙の拡がり幅について，計 算值と観測值を比較した結果である．煙の拡がり 幅とは濃度分布の標準偏差のことである．午後に なり, 大気が不安定になると煙の拡散が進み, ラ イダーの画像から拡がり幅を決めることが難しか つた。そのため，計算と観測の比較は 11 時と 12 時について行った。図ー6は图-4 と同様, 計算 值を 12 時の結果, 観測值を 11 時 21 分〜 12 時 29 分の 6 回分の平均值で比較したものである. 計算 值の方が観測值より大きくなっているが，これは， 前者が時間平均値, 後者が 1 分以内の短時間值を 示すと考えれば説明がつく. 煙の拡がり幅は平均 化時間（観測時間）が長くなるほど，拡散に寄与 する渦の周波数領域が広がるため大きくなる．鉛

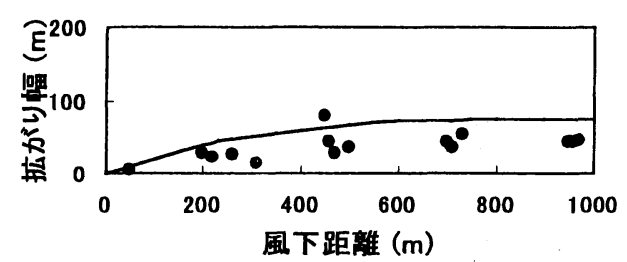

(b) 12 時

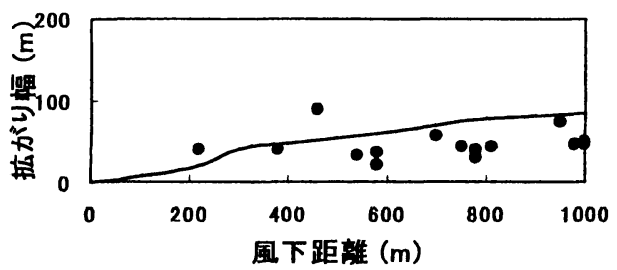

図-5 鉛直方向の煙の拡がり幅の計算結果と 観測結果の比較 $(-$ : 計算結果, ○ : 観測結果)

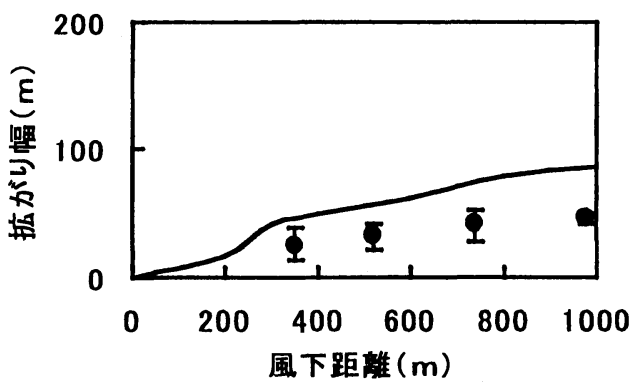

図-6 鉛直方向の煙の拡がり幅の計算結果と 観測結果の比較 : 観測值は 6 回分の平均 (一：計算結果, ○：観測結果の平均, I：観測値の最大と最小の幅）

直方向の煙の拡がり幅については, 地面の存在に よって乱れの長周期成分がカットされるため, 平 均化時間の影響は 10 分程度までしかおよばない ${ }^{15}$. 1 走査あたりのライダーの観測時間を仮に 30 秒と して，平均化時間の $1 / 5$ 乗則を用いると，観測さ れた鉛直方向の煙の拡がり幅は(10 分/0.5 分) ${ }^{1 / 5}$ 倍, つまり 2 倍近く（1.8 倍）まで大きくなり, 計算值 とほぼ一致する. 以上から，本数值モデルにより， 拡散を含めた排煙上昇過程を比較的精度よく予測 できるといえる。 


\section{5. 実地形内での大気拡散予測}

前章で数值モデルを用いて，排煙上昇過程の予 測が可能なことがわかった。本章では実地形を対 象に，排煙上昇過程を含めて拡散計算を行い，そ の結果を野外トレーサ実験の結果により検討した。

図ー7に対象地域を示す. 煙源位置が々印で示 されている.この地点の東経は 132.2 度, 北緯は 34.1 度である. 破線は地形の等高線で $200 \mathrm{~m}$ 間隔 に引かれている. 図の北側の最高標高は約 $500 \mathrm{~m}$ で, 北西部には $1000 \mathrm{~m}$ を超える山がある. 東側は 海である. 煙突実高が $200 \mathrm{~m}$ であるので, 本研究 の対象地域は, 比較的よく用いられる地形の複雑 度の基準「煙突実高を上回る高度の地形的特徵を もつ地域を複雑地形とみなす」 ${ }^{16) 117}$ によれば複雑 地形と言える. ARC1 〜 6に示した○は, 野外実 験のトレーサガスのサンプリング地点である. 図 には実線の等值線で地表濃度分布の計算結果例 （14 時 30 分〜 15 時の平均）が示されている. 濃 度の值は外側から $10,50,100,400$ ppt である. 野外で は風向は一定でなく常に変化する. そこで, 本研 究の数值モデルでは風向変化に対応させて粒子を 放出し，その粒子を乱流により式(1)，(2)に従つ て拡散させることにした．粒子を放出する際の粒 子移動の方向は以下の確率により決めた。

$$
w(\phi)=\frac{1}{\sqrt{2 \Pi} \sigma_{\mathrm{D}}} \exp \left(-\frac{\Phi^{2}}{2 \sigma_{\mathrm{D}}^{2}}\right)
$$

ここで, $\mathrm{w}(\phi)$ は風向 $\phi$ の出現頻度, $\sigma_{\mathrm{D}}$ は風向変 動の標準偏差である， $\sigma_{\mathrm{D}}$ として煙源高さにおける ドップラー音波レーダの観測值を利用した。ただ し，ドップラ一音波レーダの観測值は比較的大き なボリューム平均であるため，超音波風向風速計 の值より高い值となる，そこで，本研究では原子 力安全研究協会が実施した両風速計の比較試験結 果を参考に，ドップラー音波レーダの観測值を 2.4 分の 1 した值を用いた。実験期間中の $\sigma$ 。はおよそ 15 度であった。

図ー7に示した濃度分布の計算結果を野外トレ 一サ実験の結果と比較した。トレーサガスのサン プリング地点について, 計算と実験の濃度を比較 した結果を図ー8に示す. 各種記号によりサンプ リング $\mathrm{ARC}$ (弧) 1 〜 6別している. 図中の 実線は計算值と実験值が一致することを示し, 両 側の破線はファクター 2 および 10 で一致すること を示す.ファクター 2 以内での一致度は $30 \%$ 弱で ある. 発電所のような大規模煙源を対象に提案さ れた排煙上昇式（上昇過程を考慮しない）とガウ
ス型プルームモデル（地形影響を考慮しない） ${ }^{18}$ で予測した場合，ファクター 2 以内の一致度は 15 $\%$ 弱で, 本研究の数值モデルの約半分に過ぎない. 一般に計算と野外実験で時間と場所を同じにした 場合，両者の濃度の一致度は低い。米国環境保護 庁の複雑地形を対象としたプロジェクト

(Complex Terrain Model Development Project) の中 で，最も高度なモデルでもファクター 2 以内の一 致度は $20 \sim 30 \%$ あっった ${ }^{19}$ 。このことから, 図 -8の結果はそれほど悪くないと言える.

計算と野外実験で時間と場所を同じにした比較 は，計算で入力として与える風向により予測精度 が左右されるため, 数值モデルの評価指標として 必ずしも最適とは言えない。そこで，よく用いら れるのが数值モデルと野外実験のそれぞれの煙軸 上濃度を比較する方法である.図ー9 は計算と野 外卜レーサ実験で，それぞれの地表煙軸上濃度分 布を比較した結果である.（a)は 14 時〜 14 時 30 分の平均濃度, (b)は 14 時 30 分〜 15 時の平均濃 度を示す。

図には破線で排煙上昇をコンケイウ式 ${ }^{20)}$ ，拡散 を ERT モデル ${ }^{21} て ゙$ 計算した結果が示されている. この上昇式，拡散モデルの組み合わせは，わが国 で大気拡散におよぼす地形影響を評価するために しばしば用いられている。なお，コンケイウ式は 排煙上昇過程を考慮できない. ERT モデルはガウ ス型流跡モデルで, 煙軸の評価に地形は考慮され るが，拡散におよぼす地形影響は考えていない。 図から明らかなように，野外実験結果に見られる 煙源近くの高濃度が予測されていない。これは， 主に排煙上昇を過大に予測したことと地形等によ る鉛直方向の拡散の増加がモデルで扱えないこと が原因である. 一方, 実線は本研究の数值モデル の結果で, 各風下距離における最大濃度は, 野外 実験とよく一致している．特に，煙源近くの高濃 度の予測に対して, 本数值モデルはコンケイウ式 ・ERT モデルと比べて濃度予測の精度がよい。

\section{6. まとめ}

大気拡散の有効な予測手法として，ラグランジ ユ型粒子モデルがある.本研究では, ラグランジ 工型粒子モデルに排煙上昇過程を組み込み，その 予測精度を野外トレーサ実験を実施して確かめた。 得られた成果を以下にまとめる.

（1）非正規，非均質場に対する適用性をもつと言 われている Thomson の 1987 年のモデルをもとに， 


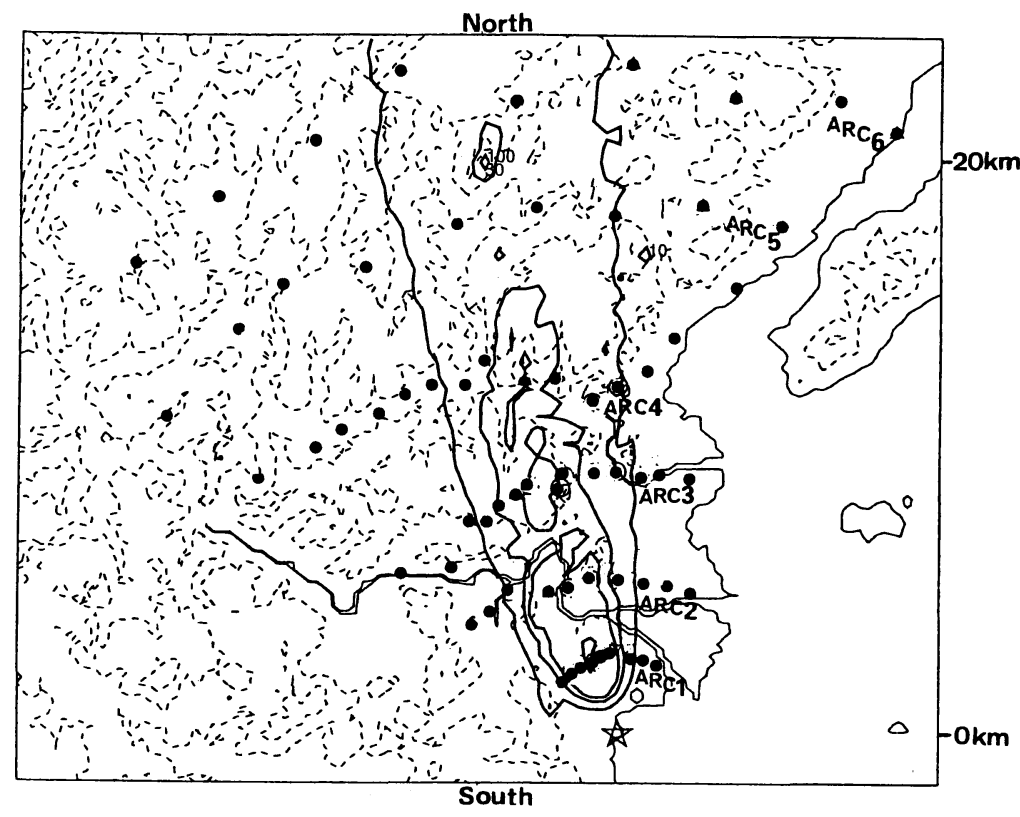

図-7 対象地域と地表濃度分布の計算結果（実線の等值線）

○は野外トレーサ実験のサンプリング地点

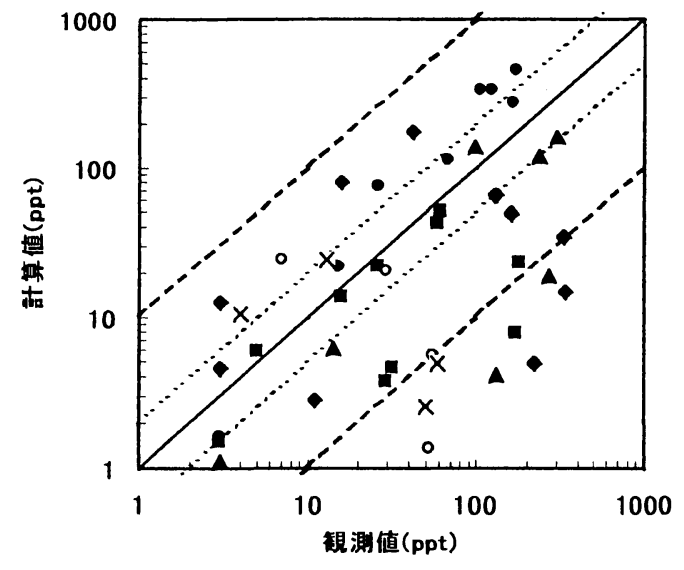

図ー8 計算結果と野外トレーサ実験結果の比較 （14 時 30 分〜 15 時の平均濃度），:ARC1,

\section{$\triangle:$ ARC2, $:$ :ARC3, $:$ :ARC4,O :ARC5, $\times:$ ARC6}

大気安定度を考慮して排煙上昇過程を予測する手 法ならびに実地形上での大気拡散を排煙上昇過程 を含めて予測する手法を開発した。

（2）数值モデルによる排煙上昇過程の予測結果の 妥当性は, 実煙源の排煙を対象に行ったライダー 観測の結果と比較して確認した。煙の上昇過程は (a)

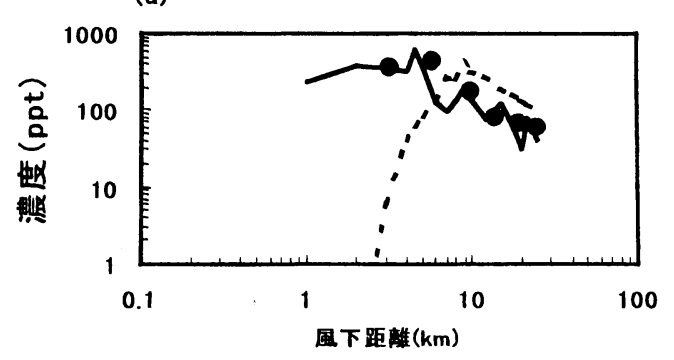

(b)

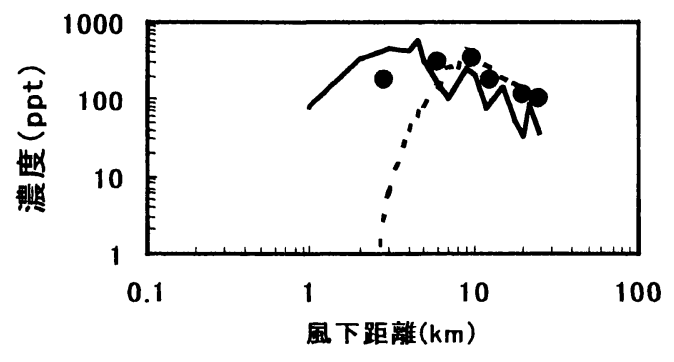

図－9地表煙軸上濃度分布の計算結果と野外 トレーサ実験結果の比較 $(-$ : 計算, ○ : 実験, -..-- : ERT モデル)

(a) 14 時〜 14 時 30 分，(b)14 時 30 分 15 時 
計算と実験でよく一致した。煙の拡がり幅は, 計 算値の方が観測值より高かった。これは，前者が 時間平均值, 後者が 1 分以下の短時間值を示すか らと考えられる.このことを考虑すれば，本数值 モデルにより, 拡散を含めた排煙上昇過程を比較 的精度よく予測できるといえる.

（3）実地形を対象に排煙上昇過程を含めて数值モ デルで大気拡散の計算を行い，その結果を野外卜 レーサ実験の結果をもとに検討した。評価期間と 場所を一致させて, 計算結果と実験結果を比べる と, ファクター 2 以内での一致度は $30 \%$ 弱であっ た。この一致度は米国環境保護庁の高度なモデル の予測精度と同程度であり，悪くない結果と言え る.計算と実験で，それぞれの地表煙軸上の濃度 分布同土を比較すると両者よい一致が得られた。 特に, 本数値モデルは, 煙源近くの高濃度の予測 に対して，地形影響評価にしばしば用いられるコ ンケイウ式・ERT モデルと比べて濃度予測の精度 がよい。

（4）以上から,ラグランジュ型粒子モデルを用い て, 煙突実高を上回る高度の地形的特徵をもつ地 域での大気拡散を, 排煙上昇過程を含めて予測で きることがわかる．急峻でない実地形の場合, 孤 立峰や 2 次元的な峰で顕著に見られる渦領域など 局所的な流れの影響が適度な起伏により緩和され るため, 本予測のように気流場の計算に静力学モ デルを用いても，比較的よい予測結果が得られた と考える. 地形に沿った座標系における静力学平 衡の仮定は, 地形勾配が 5 度では十分に妥当で, 45 度では大きすぎて適用できないという指摘があ る ${ }^{221}$. 地形勾配が $20 \sim 30$ 度を超えて大きくなっ たり，地物によってダウンドラフトや煙の巻き込 みが卓越する場合は, 静力学モデルを用いた予測 には限界がある. 今後は, 本モデルを他の地点や 非正規性の乱れが強い場へ適用して, より広範な 地形, 気象条件のもとでの検証を進めることが肝 要である.また, 地物の形状によっては, 気流場 の予測に非静力学モデルの導入をはかる必要があ る.

謝辞 : 本研究を実施するにあたり, (財) 日本気 象協会竹内清秀相談役, 安達隆史専任主任技師, 工学院大学北林興二教授, (財) 電力中央研究所 四方浩名誉研究顧問, 中央大学日野幹雄教授, 大 阪大学山口克人教授, （財）日本気象協会横山長 之参与にご指導を頂いた。また, SRI International の Dr.E.Uthe, R.Kaiser 氏にはライダー観測にご尽力 頂いた。ここに深甚なる謝意を表す.

\section{参考文献}

1) Thomson, D.J.: Criteria for the selection of stochastic models of particle trajectories in turbulent flows, J. Fluid Mech., Vol.180, pp. 529-556, 1987.

2）市川陽一, 佐田幸一, 朝倉一雄 : 高次の乱流統計量を もとにした大気拡散モデルーラグランジュ型粒子モ デルを軸としてー，大気污染学会誌，Vol.29, pp.297-312, 1994.

3) Luhar, A.K. and Britter, R.: A random walk model for dispersion in inhomogeneous turbulence in a convective boundary layer, Atmos. Environ., Vol.23, pp.1911-1924, 1989.

4) Weil, J.C.: A diagnosis of the asymmetry in top-down and bottom-up diffusion using a Lagrangian stochastic model, J. Atmos. Sci., Vol.47, pp.501-515, 1990.

5) Ichikawa, Y., Sada, K. and Asakura, K.: Simulation of turbulent dispersion phenomena in a complex terrain using a Lagrangian particle dispersion model, Flow modeling and turbulent measurements VI, Chen, Shih, Lienau and Kung eds, Balkema, Rotterdam, pp.739-746, 1996.

6) Rodean, H.C.: The universal constant for the Lagrangian structure function, Phys. Fluids A, Vol.3, pp.1479-1480, 1991.

7) Du, S., Sawford, B.L., Wilson, J.D. and Wilson, D.J.: Estimation of Kolmogorov constant $\left(\mathrm{C}_{0}\right)$ for the Lagrangian structure function, using a second-order Lagrangian model for grid turbulence, Phys. Fluids, Vol. 7, pp.3083-3090, 1995.

8) Luhar, A.K. and Britter, R.E.: Random-walk modelling of buoyant-plume dispersion in the convective boundary layer, Atmos. Environ., Vol. 26A, pp.1283-1298, 1992.

9) Slawson, P.R. and Csanady, G.T.: The effect of atmospheric conditions on plume rise, J. Fluid Mech., Vol. 47, pp.33-49, 1971.

10)Gibson, M.M. and Launder, B.E.: Ground effects on pressure fluctuations in the atmospheric boundary layer, $\mathbf{J}$. Fluid Mech., Vol. 83, pp.491-511, 1978.

11)Sada, K., Ichikawa, Y. and Asakura, K.: Numerical simulation of diurnal atmospheric flow variations in a coastal complex terrain area and comparison of results with field observations, 11th symposium on turbulent shear flow, Vol. 2, pp.p2-7-p2-12, 1997.

12) Hanna, S.R. Briggs, G.A. and Hosker, R. P. Jr.: Handbook on Atmospheric Diffusion, p.11, Technical Information Center, U.S.Department of Energy, 1982.

13 )伊藤昭三：環境工学一大気編入門一, pp.190-196, 朝 倉畫店, 1984.

14)Uthe, E.E.: Application of surface based and airborne lidar systems for environmental monitoring, J. Air Pollution Control Association, Vol. 33, pp.1149-1155, 1983.

15)森口實, 千秋鋭夫, 小川弘：環境污染と気象 大気環 境アセスメントの技術, pp.159-160, 朝倉書店, 1990 . 16) Bowne, N.E., and Londergan, R.J.: Summary of results and 
conclusions for the EPRI plume model validation and development project: Moderately complex terrain site, EPRI EA-3755, Electric Power Research Institute, 1985.

17)厚生省生活衛生局水道環境部環境整備課監修: ごみ焼 却施設環境アセスメントマニュアル, p.26, （社）全 国都市清掃会議，1986.

18)朝倉一雄, 四方浩: 火発電所排煙の大気拡散予測手 法, 大気污染学会誌, Vol. 18, pp.353-369, 1983.

19) United States Environmental Protection Agency: Project Report, EPA Complex Terrain Model Development: Final Report. 1987.
20)環境庁大気保全局大気規制課編：窒素酸化物総量規制 マニュアル [増補改訂版]，pp.190-191, 公害研究対 策センター, 1995.

21)Hanna, S.R. Briggs, G.A. and Hosker, R. P. Jr.: Handbook on Atmospheric Diffusion, pp.84-86, Technical Information Center, U.S.Department of Energy, 1982.

22)Pielke, R.A.: Mesoscale Meteorological Modeling, p.121, Academic Press, 1984.

(1999. 5. 12 受付)

\title{
PREDICTION OF ATMOSPHERIC DISPERSION CONSIDERING PLUME RISE USING A LAGRANGIAN PARTICLE DISPERSION MODEL
}

\author{
Yoichi ICHIKAWA, Yukio AKAI and Koichi SADA
}

\begin{abstract}
Atmospheric dispersion considering plume rise was predicted using a Lagrangian particle dispersion model. The governing equations of the model are stochastic differential equations which represent the random motion of a particle. The vertical component of the equations includes an acceleration term due to buoyancy. Lidar observations of plume rise and field tracer experiments were conducted at a power station to examine the validity of the results from the dispersion model. Good agreement was obtained between the dispersion model and the Lidar observation of the plume trajectory. The calculated result of the spread of the plume was slightly larger than the observed one. This is reasonable considering that the former represents the time average while the latter represents the instantaneous value. The dispersion model was applied to the prediction of concentrations in a real terrain and its validity was verified through comparison with the results of the field tracer experiment.
\end{abstract}

